\title{
Gingival Spindle Cell Carcinoma
}

National Cancer Institute

\section{Source}

National Cancer Institute. Gingival Spindle Cell Carcinoma. NCI Thesaurus. Code C129289.

A poorly differentiated squamous cell carcinoma that arises from the gingiva. It is characterized by the presence of malignant pleomorphic spindle cells. 